\title{
5 La Revolución de las Petunias
}

Con su permiso, hoy me toca fabular, y la recreación de esta historia increíble bebe directamente de la vivencia de muchos mayores, que en los últimos tiempos, arremolinados por la brutal crisis económica, han visto cómo comenzaba la revocación de un rol perdido al convertirse en sustento de muchos de los que años atrás ignoraban, cuando no denostaban, a este grupo de población.

Una nueva revolución está en la fragua y los cabecillas peinan canas, caminan despacio y su tez da fe de un tesoro de muchos tiempos, pero son conscientes de que sus reivindicaciones ahora pueden ser escuchadas, que puede ser un buen momento, para, megáfono en mano que amplifique su debilitada voz, ajustar las tuercas a una sociedad poco sensible. Hoy este grupo sale de las trincheras alimentado por la fortaleza que les dan los que nuevamente viven en sus casas o compartiendo sus depauperadas pensiones o esos ahorros de toda una vida, estimulados por considerarse de nuevo útiles, por creer que puede ser un buen momento para alentar ese cambio.

No están propiciando una revolución violenta, ni alocada, ni ruidosa, más bien están tramando una llamada de atención para que nuevas generaciones puedan realmente disfrutar de lo conseguido; un cambio profundo que lleva como bandera el reconocimiento, la consideración hacia un grupo que había perdido, calladamente, atributos de ciudadanía.

Las petunias son plantas de invierno, duraderas y fáciles de cuidar, porque se adaptan prácticamente a cualquier zona climática. Quedan perfectas en cualquier espacio, siempre y cuando no reciban sol y no estén expuestas a la lluvia o al viento. Si las colocas en una jardinera, deja distancia entre ellas para que tengan espacio cuando crezcan.

A los mayores de nuestra sociedad, especialmente a los más añosos y dependientes, los hemos situado en la zona más fría de su vida, de su viaje y, paradójicamente, hemos procurado conquistas que hacen que estos periodos de silencio se puedan prolongar hasta cotas nunca pensadas, y se preguntan: ¿de qué sirve una vida sin vida, un respirar en sombra, un esperar sin fecha, un invierno sumado a otro invierno?

Los mayores de nuestra sociedad han cedido a esta su valía, han contribuido con su vida a construir lo que disfrutamos, y recibido a cambio, en muchas ocasiones, solo incomprensión. Los mayores, los muy mayores, precisan de cuidados para que conserven el máximo de su vitalidad o se marchiten con dignidad y no tengan duda de que mayoritariamente son fáciles de cuidar, participan y se dejan cuando no pueden hacerlo de forma autónoma, aunque complejos en su hechura, agradecidos cuando se planifican y conjugan entre profesionales especializados y familias con deseo. Los mayores que conozco se adaptan prácticamente a cualquier espacio, a cualquier hábitat, siempre que en el ambiente haya "calor" y no estrechamente ligado a la temperatura de la estancia. Los ancianos no solo quedan perfectos en cualquier emplazamiento, sino que si se les permite, crean esa escena, la inundan con su experiencia, la tintan con su cariño, la viven y hacen vivir con verdadera intensidad. Los mayores a buen seguro soportan peor las inclemencias del tiempo, el fogonazo de un sol despreciativo y los temporales de desplantes o malos gestos. Su corazón es menos resistente a estos avatares, máxime cuando proceden de sus propios esquejes. Los más veteranos de nuestra comunidad necesitan su espacio, necesitan de una libertad que, no tengamos duda, 


\section{Editorial}

8

revertirá sobre nosotros, necesitan rebajar la presión a la que a menudo los sometemos con "misiones" de custodia y cuidado, necesitan seguir creyendo y apostando por que cada nuevo invierno se vuelvan a emplumar de vistosas flores.

Esta Revolución de las Petunias es solo un titular de un movimiento que pudiera ser.

Un consejo final para las petunias... no mojes las flores al regar. Sus pétalos se marchitan con el agua.

Un consejo final hacia los mayores... no dejes que sus lágrimas, por incomprensión o desaliento, desdibujen a seres tan valiosos.

J. Javier Soldevilla Agreda

Director de Gerokomos 